\title{
The effect of Global Linkages on Stock Market Volatility: A study on selected Developed and Developing Markets
}

\author{
Charithra $\mathbf{C ~} \mathbf{M}^{1}$ and Mukund Sharma ${ }^{2}$ \\ ${ }^{1}$ Assistant Professor and ${ }^{2}$ Professor, \\ BNM Institute of Technology, Bangalore, India.
}

CITATION: Charithra, C M and Sharma, Mukund (2019), "The effect of Global Linkages on Stock Market Volatility: A study on selected Developed and Developing Markets", MERC Global's International Journal of Management, Vol. 7, Issue 4, pp. 260-265.

ARTICLE HISTORY: Submitted: April 24, 2019, Revision received: May 28, 2019, Accepted: June 24, 2019

ARTICLE TYPE: Research paper

\section{ABSTRACT}

The increased global linkages give an investment opportunity to invest in equities across the global markets. This linkage can be the reason for the spillover of the volatility from one market to the other. This paper makes an attempt to understand the effect of global linkages on the volatility of the stock market. For the purpose of study, stock index data of selected developed and emerging markets were collected and tested to see if there is variation across time and if yes uniformity of variation was also tested. It was found from analysis that the variation across the countries was found to be uniform and most of the pairs of countries had a positive integration between them. It was found from examination that there is no significant difference in the extent volatility across the countries.

KEYWORDS: Spill over, Stock market volatility, Developed markets, Emerging markets.

\section{BIBLIOGRAPHY}

1. Eun, Cheol S. and Shim, Sagdal (1998), "International transmission of stock market movements", The Journal of Financial and Quantitative Analysis, Vol. 24, No. 2, June.

2. Evans, M. D. D. and Hnatkovska, V. (2005), "International Capital Flows, Returns and World Financial Integration", NBER Working Paper No. 1170.

3. Jaquar, Sharudhin and Johari, Anitha (2013), "An econometric Analysis and co-movement of Stock market volatility between China and ASEAN-5", International Journal of Business and Social Science, Vol. 4, No. 14, November.

4. Johnson, R. and Soenon, L. (2002), "Asian Economic Integration and Stock Market Comovement", The Journal of Financial Research, Vol. 25, No. 1.

5. Kumar, K. Kiran and Mukopadyay, Chiranjit, (2002), "A case on US and India".

6. Liu, Y. Angela; Ming-Shiun, Pan and Joseph, C.P. Shieh (1998), "International transmission from Stock price movements: Evidence from the U.S and five Asia Pacific markets", Journal of Economics and Finance, Vol.22, No.1, March. 